\title{
Evaluation of monotonic trends for streamflow in austral Amazon, Brazil: a case study for the Xingu and Tapajós rivers
}

\author{
L. Z. Moura \\ Universidade de Brasília - PTARH, Brasilia, Brazil \\ Correspondence to: L. Z. Moura (lzandonadimoura@gmail.com)
}

Received: 11 March 2015 - Accepted: 11 March 2015 - Published: 12 June 2015

\begin{abstract}
This paper has the goal of evaluating monotonic trends in the Xingu and Tapajós river basins in the Austral Amazon region, Brazil. Non-parametric statistical tests such as Mann-Kendall, Bootstrap MannKendall, Sen and Bootstrap Sen are applied on streamflow gauging stations data, to determine the significance and magnitude of possible trends. Data in these river basins is relatively scarce, with time series ranging from twenty to forty years, having many gaps. Former studies indicate a decreasing trend for both annual average and minimum streamflow values in the Tapajós river basin, with $99 \%$ confidence level, and a decrease in maximum values in the Xingu river basin, with $90 \%$ confidence level. However, past analyses have only used one station near the basin outlet. This study uses data from 7 gauging stations in the Xingu basin and 14 stations in the Tapajós basin. Results indicate opposite trends at the $95 \%$ confidence level for different regions in the basins, and for different flow regimes. For the Xingu river basin, trends in the minimum flow for different sub-basins even out at the Altamira station, near its outlet. For the Tapajós river, the southeastern part of the basin has increasing trends, while the southwestern part decreases. At the Itaituba station, they also balance out.
\end{abstract}

\section{Introduction}

The Tapajós and Xingu river basins are located in the Southern Part of the Amazon basin, in the states of Mato Grosso and Pará, Brazil (Fig. 1). These two rivers are among the main tributaries of the Amazon river, whose basin is the largest in the world, both in area as in average flow - approximately 6 million $\mathrm{km}^{2}$ and $209000 \mathrm{~m}^{3} \mathrm{~s}^{-1}$, respectively. The Tapajós river basin has around $492 \times 10^{3} \mathrm{~km}^{2}$ drainage area (ANEEL, 2009) and its flow at the river gauging station of Itaituba is about $11700 \mathrm{~m}^{3} \mathrm{~s}^{-1}$. The Xingu river basin at the hydroelectric development site of Belo Monte represents $449 \times 10^{3} \mathrm{~km}^{2}$ drainage area (ANEEL, 2008) and its average flow is of $7800 \mathrm{~m}^{3} \mathrm{~s}^{-1}$ at the river gauging station of $\mathrm{Al}-$ tamira.

There is a relevant spatial variability in precipitation in the Amazon basin, partly due to its considerable latitudinal extension. The rainiest regions, with precipitations of $3000 \mathrm{~mm} \mathrm{yr}^{-1}$ or more, are located in the Amazon delta, close to the Atlantic Ocean. The low portion south of the basin (outside the Andes) presents precipitation between 500 and $3000 \mathrm{~mm} \mathrm{yr}^{-1}$, with the rainy season between December and January.

The river discharge interannual variability is related to fluctuations in the climatic factors such as the sea surface temperature in the Northern Atlantic an in the Equatorial Pacific (El Niño and La Niña). In El Niño (La Niña) years, the discharges diminish (increase), especially in the basin central regions. Some studies (Espinoza Villar et al., 2009) report interdecadal oscillations of 15.5 years in the minimum discharges, 17 years in the average discharges and bidecadal oscillations in the maximum discharges. The oscillation in the average discharge is connected to the South American Monsoon System cycle. As for the maximum discharges, the lowest values are related to the Tropical North Atlantic Ocean and Pacific Ocean surface temperature variability and the highest values are related to the South Atlantic Ocean surface temperature variability.

These subbasins are relevant to the Brazilian economy in the energetic standpoint, due to the planned expansion in 


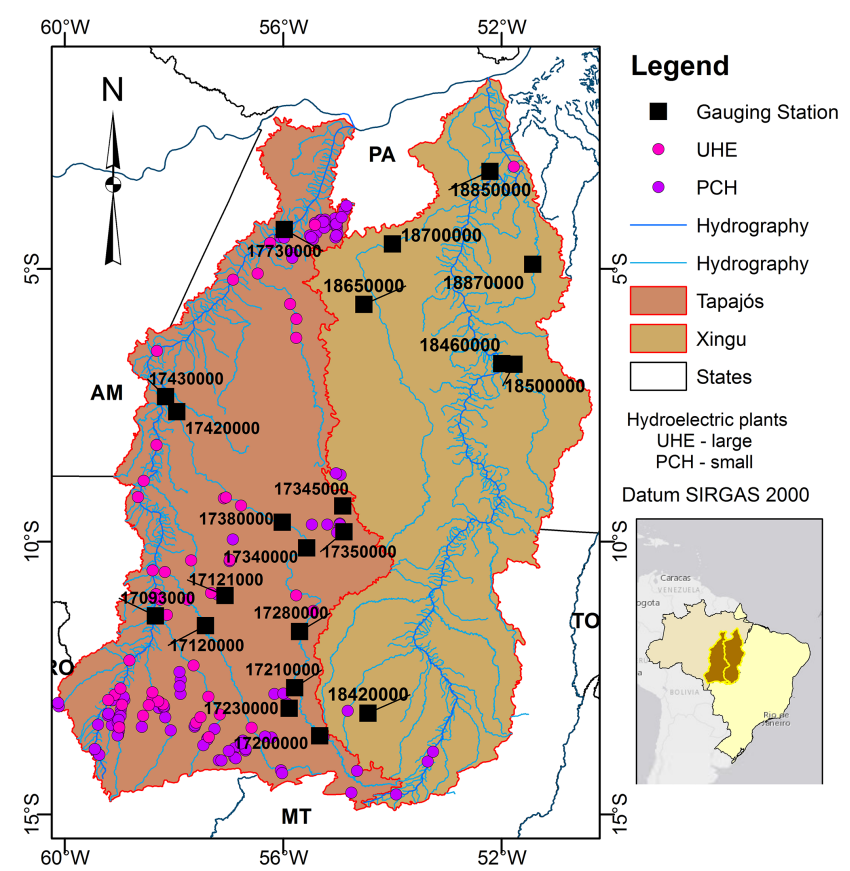

Figure 1. Map of the Tapajós and Xingu river basins showing the location of discharge 3 gauging stations and hydroelectric plants (built and planned).

hydroelectric infrastructure. In Brazil, hydroelectricity represents around $77 \%$ of electric generation and $15 \%$ of the entire domestic power supply. In 2010, the country's unused hydroelectric potential was estimated in $132 \mathrm{GW}$, while installed or in construction capacity was of $100 \mathrm{GW}$ (Soito and Freitas, 2011). Of the unexplored potential, about $45 \%$ was located in the North region and $18 \%$ in the Centre-West region, which also contributes to the Amazon basin. On the other side, $48 \%$ of the installed or in construction capacity were in the South or Southeast regions.

The trend for hydroelectric projects in the Amazon region is of run-of-the-river plants, that is without large dams that make possible the seasonal regularization of discharges. From the socio-environmental point of view, this is advantageous, since the so-called power density (installed MW per flooded $\mathrm{km}^{2}$ ) is higher than the historical project values. However, these plants' power generation is more exposed to climatic fluctuations, as well as the country's energetic matrix as a whole. There are studies indicating that occurrences of the El Niño Southern Oscillation phenomenon (ENSO) have been more frequent, long and severe in the past 20 to 30 years than in the preceding 100 years. With the global warming phenomenon, increases in temperature between 0.6 and $0.9^{\circ} \mathrm{C}$ were registered in the past 100 years. Some climate change models, such as the Hadley Center's, predict for the year of 2050 average reductions of 150 to $250 \mathrm{~mm} \mathrm{yr}^{-1}$ in precipitation for the region. A review is available in Soito and Freitas (2011).
Another relevant aspect in these basins is their land use change dynamic, for being inserted at the regional context of the so-called "deforestation arch", where the expansion of lumbering and cattle-raising activities, and posteriorly agriculture generate large-scale change. These changes may have important ecological implications, such as increased tree mortality, risk of fire and acute biodiversity loss (Davidson et al., 2012). It is still not possible to determine if recent droughts are a sign of transition to a disturbance regime due to local changes, or if precipitation and streamflow trends are mainly due to climate variability which makes it hard and very risky to infer that these non-stationarities will persist (Serinaldi and Kilsby, 2015).

\section{Materials and methods}

\subsection{Data}

Daily flow data $\left[\mathrm{m}^{3} \mathrm{~s}^{-1}\right]$ were used, available in the Hidroweb application, from Brazil's National Water Agency (ANA, 2014). The river gauging stations with longest time series and less gaps in the data were selected, resulting in seven stations in the Xingu river basin and fourteen in the Tapajós river basin, detailed in Tables 1 and 2, respectively, also in Fig. 1, along with hydroelectric plant sites (planned or built).

Considering that in the region the hydrological year begins in October, the annual minimum and maximum daily flows were selected, and the annual average was calculated. When there were less then 75 data points in the dry (humid) season, which for simplicity was considered the second (first) semester, a year was considered a data gap for the minimum (maximum) streamflow. The so produced time series were then submitted to statistical tests for the detection of monotonic trends.

\subsection{Statistical tests}

Five different tests (Mann-Kendall, Bootstrap MannKendall, Sen, Bootstrap Sen and linear regression) were used for the evaluation of statistical significance of monotonic trends. The statistical tests were applied using a degree of significance alpha $\alpha=0.05$. The trend direction (increase or reduction) was interpreted by the angular coefficient of the linear regression and by the Sen's slope $(B)$ signal. Following the literature, all resampling tests were performed using 1000 (one thousand) repetitions.

The Mann-Kendall trend test is non-parametric and rankbased, having higher power than slope-based tests (Yue et al., 2002). The bootstrap version of the Mann-Kendall test (Yue and Pilon, 2004) uses the same test-statistic, however its probability distribution is obtained empirically, for each provided time series, by means of a determinate amount of random resampling of the data, with replacement. In this manner, synthetic time series are generated, and the test-statistic 
Table 1. River gauging stations in the Xingu river basin utilized in this study.

\begin{tabular}{llrlll}
\hline Code & Name & $\begin{array}{r}\text { Drain Ar. } \\
{\left[\mathrm{km}^{2}\right]}\end{array}$ & Beginning & End & \# years \\
\hline 18420000 & Fazenda Itaguaçu & 3840 & May 1977 & Oct 2009 & 32 \\
18460000 & Boa Sorte & 210000 & Oct 1975 & Dec 2005 & 30 \\
18500000 & Boa Esperança & 42400 & Jan 1976 & Apr 2009 & 33 \\
18650000 & Cajueiro & 35600 & Nov 1975 & Dec 2006 & 31 \\
18700000 & Pedra do Ó & 122000 & Jan 1976 & Oct 2009 & 34 \\
18850000 & Altamira & 448000 & Jan 1971 & Jan 2013 & 42 \\
18870000 & Aldeia Bacajá & 12800 & Jul 1976 & Jun 1999 & 23 \\
\hline
\end{tabular}

Table 2. River gauging stations in the Tapajós river basin utilized in this study.

\begin{tabular}{llrllc}
\hline Code & Name & $\begin{array}{r}\text { Drain Ar. } \\
{\left[\mathrm{km}^{2}\right]}\end{array}$ & Beginning & End & $\begin{array}{c}\text { \# } \\
\text { years }\end{array}$ \\
\hline 17093000 & Fontanilhas & 55900 & Jan 1978 & Mar 2013 & 35 \\
17120000 & Porto dos Gaúchos & 37100 & Sep 1973 & Dec 2007 & 34 \\
17121000 & Caiabis (Balsa - Itapaiuna) & 9750 & Aug 1979 & Jun 1997 & 18 \\
17200000 & Porto Roncador & 10800 & Aug 1973 & Feb 2012 & 39 \\
17210000 & Teles Pires & 13900 & Apr 1976 & Jan 2013 & 37 \\
17230000 & Pch Canoa Quebrada & 5435 & Aug 1973 & Aug 2011 & 38 \\
17280000 & Cucas do Rio Verde & 34600 & Nov 1975 & Feb 2013 & 37 \\
17340000 & Indeco & 52200 & Oct 1975 & Feb 2013 & 37 \\
17345000 & Base do Cachimbo & 465 & Jun 1980 & Jan 2010 & 30 \\
17350000 & Cachimbo & 1010 & Mar 1979 & Feb 2013 & 34 \\
17380000 & Jusante Foz Peixoto & 81600 & Sep 1980 & Jan 2013 & 32 \\
17420000 & Te Azevedo & 138000 & Nov 1975 & Dec 2009 & 34 \\
17430000 & Barra do São Manuel & 333000 & Oct 1975 & Apr 2009 & 34 \\
17730000 & Itaituba & 458000 & Feb 1968 & May 2013 & 45 \\
\hline
\end{tabular}

Table 3. $p$ values for the statistical tests applied to discharge time series for stations in the Xingu river basin. Bold $=$ significant $95 \%$ confidence.

\begin{tabular}{lccccccc}
\hline Station & 18420000 & 18460000 & 18500000 & 18650000 & 18700000 & 18850000 & 18870000 \\
\hline \multicolumn{7}{c}{$p$ values $Q$ minimum } \\
\hline M-K & 0.3524 & $\mathbf{0 . 0 0 4 9}$ & $\mathbf{0 . 0 0 1 8}$ & 0.1188 & 0.1737 & 0.7528 & 0.9339 \\
BS M-K & 0.3470 & $\mathbf{0 . 0 0 5 0}$ & $\mathbf{0 . 0 0 1 0}$ & 0.1030 & 0.1450 & 0.7410 & 0.8770 \\
BS Sen & 0.2170 & $\mathbf{0 . 0 0 0 0}$ & $\mathbf{0 . 0 0 1 0}$ & 0.1150 & 0.1450 & 0.5530 & 0.5970 \\
Lin. Reg. & 0.1005 & $\mathbf{0 . 0 0 0 9}$ & $\mathbf{0 . 0 0 3 0}$ & $\mathbf{0 . 0 4 8 9}$ & 0.0617 & 0.2487 & 0.3919 \\
\hline & & \multicolumn{7}{c}{$p$ values } & $Q$ mean & & & \\
\hline M-K & 0.2227 & $\mathbf{0 . 0 1 3 1}$ & 0.7443 & 0.1492 & 0.6930 & 0.6452 & 0.4440 \\
BS M-K & 0.2330 & $\mathbf{0 . 0 1 1 0}$ & 0.6890 & 0.1570 & 0.6910 & 0.6230 & 0.4410 \\
BS Sen & 0.1730 & $\mathbf{0 . 0 2 3 0}$ & 0.5650 & 0.1590 & 0.4650 & 0.4770 & 0.3310 \\
Lin. Reg. & 0.1034 & $\mathbf{0 . 0 2 3 5}$ & 0.3811 & 0.0539 & 0.4216 & 0.2768 & 0.3212 \\
\hline & & & $p$ values $Q$ maximum & & & \\
\hline M-K & 0.1489 & 0.2186 & 0.9763 & 0.5115 & 0.4275 & 0.8031 & 0.8690 \\
BS M-K & 0.1430 & 0.1990 & 0.9750 & 0.5090 & 0.4410 & 0.8030 & 0.8030 \\
BS Sen & 0.1010 & 0.1850 & 0.7670 & 0.2270 & 0.2750 & 0.6310 & 0.6350 \\
Lin. Reg. & 0.0697 & 0.1048 & 0.4904 & $\mathbf{0 . 0 4 5 7}$ & 0.2267 & 0.1836 & 0.4959 \\
\hline
\end{tabular}


Table 4. $p$ values for the statistical tests applied to discharge time series for stations in the Tapajós river basin. Bold $=$ significant $95 \%$ confidence.

\begin{tabular}{|c|c|c|c|c|c|c|c|}
\hline Station & 17093000 & 17120000 & 17121000 & 17200000 & 17210000 & 17230000 & 17280000 \\
\hline \multicolumn{8}{|c|}{$p$ values $Q$ minimum } \\
\hline $\mathrm{M}-\mathrm{K}$ & 0.0004 & 0.3579 & 0.0051 & 0.0279 & 0.3867 & 0.5264 & 0.0796 \\
\hline BS M-K & 0.0000 & 0.3550 & 0.0030 & $\mathbf{0 . 0 3 3 0}$ & 0.3490 & 0.5270 & 0.0670 \\
\hline BS Sen & 0.0000 & 0.1590 & 0.0030 & 0.0190 & 0.3650 & 0.3630 & 0.0410 \\
\hline Reg. Lin. & $\mathbf{0 . 0 0 3 7}$ & 0.0730 & 0.0003 & 0.0187 & 0.2115 & 0.1125 & 0.0313 \\
\hline \multicolumn{8}{|c|}{$p$ values $Q$ mean } \\
\hline $\mathrm{M}-\mathrm{K}$ & 0.0003 & 0.1305 & 0.1195 & 0.4873 & 0.2158 & 0.9850 & 0.9999 \\
\hline BS M-K & 0.0000 & 0.1170 & 0.0890 & 0.4610 & 0.1550 & 0.9490 & 0.9830 \\
\hline BS Sen & 0.0030 & 0.0370 & 0.0510 & 0.3610 & 0.1390 & 0.7830 & 0.7370 \\
\hline Reg. Lin. & 0.0007 & 0.0164 & 0.0287 & 0.2904 & 0.0589 & 0.3040 & 0.4418 \\
\hline \multicolumn{8}{|c|}{$p$ values $Q$ max. } \\
\hline $\mathrm{M}-\mathrm{K}$ & 0.5432 & 0.5321 & 0.0467 & 0.5765 & 0.3899 & 0.7726 & 0.8456 \\
\hline BS M-K & 0.5150 & 0.5290 & 0.0350 & 0.6250 & 0.3690 & 0.7050 & 0.8670 \\
\hline BS Sen & 0.3110 & 0.3930 & 0.0070 & 0.3270 & 0.2810 & 0.6330 & 0.6010 \\
\hline Reg. Lin. & 0.2178 & 0.2149 & 0.0191 & 0.2788 & 0.1992 & 0.2551 & 0.4499 \\
\hline Estação & 17340000 & 17345000 & 17420000 & 17430000 & 17730000 & 17350000 & 17380000 \\
\hline \multicolumn{8}{|c|}{$p$ values $Q$ minimum } \\
\hline $\mathrm{M}-\mathrm{K}$ & 0.6430 & 0.1823 & 0.7072 & 0.0042 & 0.0682 & $\mathbf{0 . 0 3 3 0}$ & 0.2145 \\
\hline BS M-K & 0.6770 & 0.1910 & 0.6990 & 0.0030 & 0.0000 & 0.0230 & 0.1910 \\
\hline BS Sen & 0.5050 & 0.0730 & 0.5470 & 0.0050 & 0.0000 & 0.0310 & 0.2670 \\
\hline Reg. Lin. & 0.2033 & 0.0541 & 0.4312 & 0.0007 & 0.0000 & 0.0142 & 0.0983 \\
\hline \multicolumn{8}{|c|}{$p$ values $Q$ mean } \\
\hline $\mathrm{M}-\mathrm{K}$ & 0.1819 & 0.1010 & 0.7614 & 0.1563 & 0.1260 & 0.2095 & 0.0211 \\
\hline BS M-K & 0.1570 & 0.0950 & 0.7230 & 0.1770 & 0.1450 & 0.2010 & 0.0090 \\
\hline BS Sen & 0.1250 & 0.0490 & 0.4830 & 0.0610 & 0.0610 & 0.2470 & 0.0430 \\
\hline Reg. Lin. & 0.2512 & 0.0694 & 0.4166 & 0.0271 & 0.0330 & 0.1853 & 0.0252 \\
\hline \multicolumn{8}{|c|}{$p$ values $Q$ maximum } \\
\hline $\mathrm{M}-\mathrm{K}$ & 0.8063 & 0.0003 & 0.7230 & 0.9999 & 0.4137 & 0.4495 & 0.0578 \\
\hline BS M-K & 0.8090 & 0.0000 & 0.7490 & 0.9770 & 0.4230 & 0.4430 & 0.0570 \\
\hline BS Sen & 0.7450 & 0.0010 & 0.4570 & 0.7870 & 0.2690 & 0.3010 & 0.0570 \\
\hline Reg. Lin. & 0.4505 & 0.0001 & 0.3872 & 0.2052 & 0.3033 & 0.2341 & 0.0351 \\
\hline
\end{tabular}

values are calculated for each one. In the trend detection test proposed by Sen (Sen, 1968), the $B$ (Sen slope) test statistic is the median of the slopes $(d)$ between all possible sequential data pairs, considering the numerator as the difference between the interest variable values (for example, flows) and the denominator as the difference between these values' occurrence time. The null hypothesis' (there is no trend) region of validity in the ordered vector of $d_{i j}$ slopes is calculated. In case a slope equal to zero is not in this interval, the null hypothesis is rejected. This test does not provide a $p$ value. The Bootstrap Sen method (Yue and Pilon, 2004) consists in generating, for each time series provided, a determinate amount of random resamplings of the data, with replacement. From these, one obtains the empirical distribution of the $B$ slope values. These values are ordered, and their accumulated probability is calculated as their order number divided by the total number of medians (number of resamplings). The linear regression test was performed using the procedures detailed in Naghettini and Pinto (2007).

\subsection{Results and discussion}

The resulting $p$ values for the tests are shown in Tables 3 and 4 for the Xingu and Tapajós rivers, respectively. Figure 2 shows the spatial distribution of detected trends.

In the Xingu river basin, trends in the minimum and mean discharges were found in the $5 \%$ significance level. For the minimum flows, the Boa Sorte station presents a decrease 

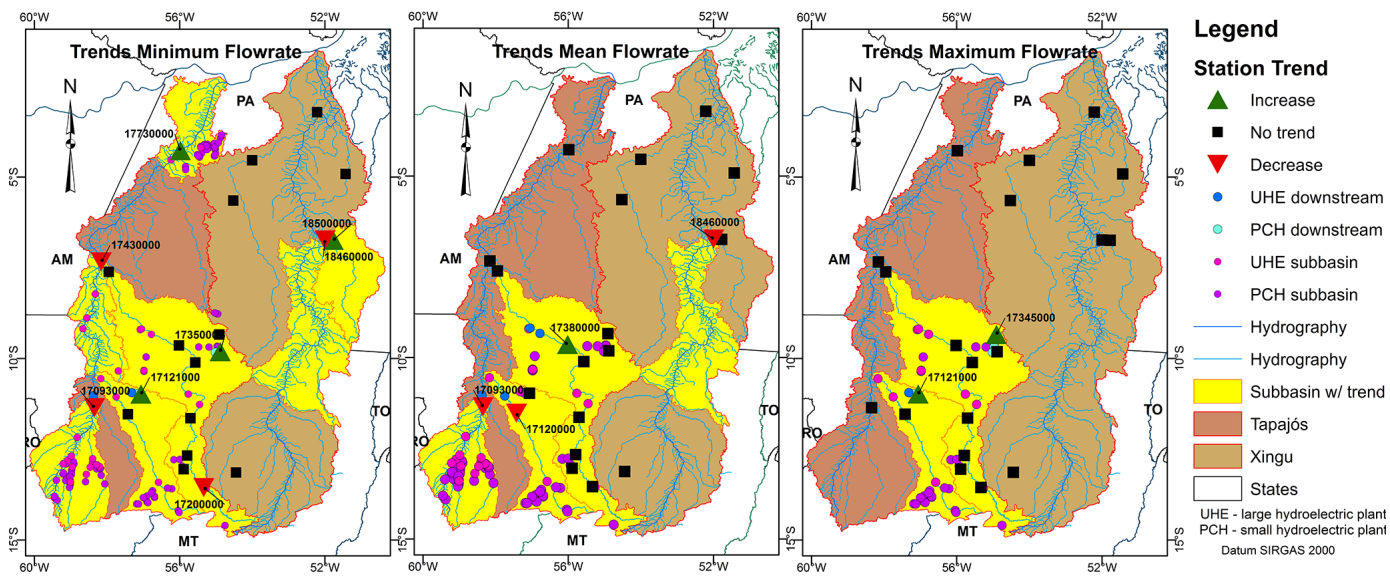

Figure 2. Map of streamflow gauging stations and sub-basins where trends were detected, and possibly affected hydroelectric sites.

Table 5. Magnitude of statistically significant (bold) or strong trends - Xingu river basin.

\begin{tabular}{lrrr}
\hline Station & 18460000 & 18500000 & 18700000 \\
\hline \multicolumn{4}{c}{$Q$ min. } \\
\hline BS Sen & $\mathbf{- 1 . 2 4 1 ~ \% ~}$ & $\mathbf{3 . 9 3 9 \%}$ & $1.796 \%$ \\
Sen & $\mathbf{- 0 . 9 6 8 \%}$ & $\mathbf{3 . 5 2 9} \%$ & $1.383 \%$ \\
Lin. Reg. & $\mathbf{- 0 . 8 6 0} \%$ & $\mathbf{3 . 3 7 2} \%$ & $1.549 \%$ \\
\hline Station & 18460000 & 18870000 \\
\hline & $Q$ mean & \\
BS Sen & $\mathbf{- 1 . 3 1 2 \%}$ & $1.207 \%$ \\
Sen & $\mathbf{- 0 . 9 0 6 \%}$ & $0.640 \%$ & \\
Lin. Reg. & $\mathbf{- 0 . 9 0 3 \%}$ & $0.693 \%$ \\
\hline
\end{tabular}

and the Boa Esperança station an increasing trend. Only the Boa Sorte station presents a significant decreasing trend in the mean flow.

In the Tapajós river basin, trends were detected in all flow regimes. For the minimum flows, different regions in the basin presented opposite behaviors. In the southeastern part, two stations present increases and one presents a decrease. In the main course of the river, two stations present negative trends for the annual minimum. However, increasing trends predominate, as is observed in the Itaituba station, almost at the basin outlet. The mean discharges portray an equilibrium among negative trends (two stations) and positive trends (one station). Two stations have positive significant trends in the maximum discharges.

Trends in $\left[\mathrm{m}^{3} \mathrm{~s}^{-1} \mathrm{yr}^{-1}\right]$ were divided by the historical mean flow for that regime (min, mean, max) to obtain their relative magnitude - listed on Tables 5 and 6 . Statistically significant trends are shaded in gray. For the Xingu river basin (Table 5), the significant trends may have practical significance, with -1 to $+3 \%$ per year slope. They however compensate each other before the river reaches the only hy- droelectric site in its lower course, the Belo Monte plant, where no trends were detected. For the Tapajós basin, most significant trends were not strong. The 17121000 - Caiabis (Balsa - Itapaiuna) Station has such high trends because its time series is very short, and has some gaps. The 17730000 - Itaituba station data results are different from other studies (Espinoza Villar et al., 2009) because different rating curves were used to calculate the flow from the river stage. This study's results in that station suffer from inconsistencies in the data, especially for minimum flows.

\section{Conclusions}

This study sought to increase the knowledge on trends in river flow in discharge gauging stations of the austral Amazon region, more specifically in the Tapajós and Xingu river basins. It has utilized data from more stations than previous studies, however their relative scarcity, gaps (inconsistencies or absence of measurements) in the time series and differences in methods (rating curves and data quality screening) remained as relevant obstacles.

Acknowledgements. Brazilian Ministry of The Environment for the support; Brazilian National Water Agency - ANA (Agência Nacional de Águas) for the data; HyBAm program for clarification of method issues; the Water Resources and Environmental Technology Graduate Program from the University of Brasília - PTARH UnB (Programa de Pós-Graduação em Tecnologia Ambiental e Recursos Hídricos) for the education provided and; colleagues from the Master's degree studies Ana Osório, Renato Amorim and Carlos Ferreira. 
Table 6. Magnitude of statistically significant (bold) or strong trends - Tapajós river basin.

\begin{tabular}{|c|c|c|c|c|c|c|c|}
\hline Station & 17093000 & 17121000 & 17200000 & 17280000 & 17350000 & 17430000 & 17730000 \\
\hline \multicolumn{8}{|c|}{$Q \min$} \\
\hline BS Sen & $-0.321 \%$ & $8.683 \%$ & $-0.417 \%$ & $\mathbf{0 , 3 3 0 \%}$ & $0.787 \%$ & $-0.580 \%$ & $5.864 \%$ \\
\hline Sen & $-0.311 \%$ & $8.683 \%$ & $-0.417 \%$ & $0.307 \%$ & $0.787 \%$ & $-0.450 \%$ & $4.586 \%$ \\
\hline Lin. Reg. & $-0.249 \%$ & $8.390 \%$ & $-0.429 \%$ & $0.306 \%$ & $1.024 \%$ & $-0.559 \%$ & $4.648 \%$ \\
\hline Station & 17093000 & 17120000 & 17380000 & 17121000 & & & \\
\hline \multicolumn{8}{|c|}{$Q$ mean } \\
\hline BS Sen & $-0.322 \%$ & $-0.431 \%$ & $0.883 \%$ & $2.449 \%$ & & & \\
\hline Sen & $-0.310 \%$ & $-0.431 \%$ & $0.631 \%$ & $2.449 \%$ & & & \\
\hline Lin. Reg. & $-0.294 \%$ & $-0.493 \%$ & $0.609 \%$ & $2.508 \%$ & & & \\
\hline Station & 17121000 & 17345000 & 17380000 & & & & \\
\hline \multicolumn{8}{|c|}{$Q \max$} \\
\hline BS Sen & $2.574 \%$ & $1.761 \%$ & $0.731 \%$ & & & & \\
\hline Sen & $1.839 \%$ & $1.761 \%$ & $0.619 \%$ & & & & \\
\hline Lin. Reg. & $1.744 \%$ & $1.732 \%$ & $0.649 \%$ & & & & \\
\hline
\end{tabular}

\section{References}

ANA, A. N. de Á.: Hidroweb - Sistema de informações Hidrológicas, available at: http://hidroweb.ana.gov.br/, last access: 1 January 2014.

ANEEL - Agência nacional de energia and elétrica: Despacho No. 2.756, available at: http://www.aneel.gov.br/cedoc/ dsp20082756.pdf (last access: 11 November 2014), 2008.

ANEEL - Agência nacional de energia and elétrica: Despacho No. 1.887, available at: http://www.aneel.gov.br/cedoc/ dsp20091887.pdf (last access: 11 November 2014), 2009.

Davidson, E. A., de Araújo, A. C., Artaxo, P., Balch, J. K., Brown, I. F., C. Bustamante, M. M., Coe, M. T., DeFries, R. S., Keller, M., Longo, M., Munger, J. W., Schroeder, W., Soares-Filho, B. S., Souza, C. M., and Wofsy, S. C.: The Amazon basin in transition, Nature, 481, 321-328, doi:10.1038/nature10717, 2012.

Espinoza Villar, J. C., Guyot, J. L., Ronchail, J., Cochonneau, G., Filizola, N., Fraizy, P., Labat, D., de Oliveira, E., Ordoñez, J. J., and Vauchel, P.: Contrasting regional discharge evolutions in the Amazon basin (1974-2004), J. Hydrol., 375, 297-311, doi:10.1016/j.jhydrol.2009.03.004, 2009.
Naghettini, M. and Pinto, É. J. de A.: Hidrologia estatística, CPRM, Belo Horizonte, Brasil, 2007.

Sen, P. K.: Estimates of the Regression Coefficient Based on Kendall's Tau, J. Am. Stat. Assoc., 63, 1379, doi:10.2307/2285891, 1968.

Serinaldi, F. and Kilsby, C. G.: Stationarity is undead: Uncertainty dominates the distribution of extremes, Adv. Water Resour., 77, 17-36, doi:10.1016/j.advwatres.2014.12.013, 2015.

Soito, J. L. da S. and Freitas, M. A. V.: Amazon and the expansion of hydropower in Brazil: Vulnerability, impacts and possibilities for adaptation to global climate change, Renew. Sustain. Energy Rev., 15, 3165-3177, doi:10.1016/j.rser.2011.04.006, 2011.

Yue, S. and Pilon, P.: A comparison of the power of the $t$ test, MannKendall and bootstrap tests for trend detection/Une comparaison de la puissance des tests $t$ de Student, de Mann-Kendall et du bootstrap pour la détection de tendance, Hydrolog. Sci. J., 49, 21-37, 2004.

Yue, S., Pilon, P., and Cavadias, G.: Power of the Mann-Kendall and Spearman's rho tests for detecting monotonic trends in hydrological series, J. Hydrol., 259, 254-271, 2002. 